\title{
First data on testate amoebae in speleothems of caves in igneous rocks
}

GONZÁlEZ LÓPEZ, L. ${ }^{1}$, VIDAL-ROMANÍ, J.R. ${ }^{1}$, LÓPEZ GALINDO, M. J. ${ }^{1}$, VAQUEIRO RODRÍGUEZ, M. ${ }^{1}$ and SANJURJO SÁNCHEZ, J. ${ }^{1}$

(1) Instituto Universitario de Geología. Universidad de Coruña, 15071 Coruña, Spain.

Corresponding author email address: juan.vidal.romani@udc.es

https://doi.org/10.17979/cadlaxe.2013.37.0.3581

\begin{abstract}
The testate amoebae form part of the habitual troglobios in caves developed in igneous rocks (plutonic and volcanic) where the little light, the persistence of humidity, the availability of silica and organic matter allow these protozoa to develop their biological cycle. This work presents a first inventory of species of amoebae testate identified in caves in igneous rocks from different parts of the World.
\end{abstract}

Key words: testate, caves in igneous rocks, amorphous opal speleothems. 


\section{INTRODUCTION}

Massifs formed by igneous rocks are characterized by their low porosity and scarce solubility, so in these cases runoff normally moves on the surface. However, runoff may drain exceptionally underground through the systems of cavities related to fractures, faults or diaclases when they are open totally or partially. When these types of caves are very large they are considered pseudokarstic systems as they are developed in non soluble rocks and are also differentiated from the karst sensu sctricto, characteristic of calcareous massifs (VIDAL ROMANÍ \& VAQUEIRO 2007; Vidal Romaní et al., 2110 a y b). Pseudokarst is also distinguished because water circulation is normally produced at low velocity as trickles which disperse slowly onto the floor, walls or ceiling of the caves. In physical continuity with these trickles, it is normal to find specific deposits (speleothems) of small dimensions and characterized by a varied mineralogical spectrum, the most frequent mineral species being: amorphous opal, evansite, pigotite, alophane, or even carbonates (FORTI, 2005; VIDAL ROMANÍ et al., 2110 a y b). These types of speleothems were first described by Caldleugh in 1829, and during a long time it was considered that they were due to the rock weathering produced by the water (VIDAL ROMANÍ et al., 1979; VIDAL ROMANÍ, 1983; VIDAL ROMANÍ \& VILAPLANA, 1984; WEBB \& FINLAYSSON, 1984). For this reason, these deposits were first characterized almost exclusively by their mineralogy ignoring their relationship with the activity of microorganisms which lived in these caves. Later, the introduction of the scanning electronic microscopy in the study of these speleothems (KASHIMA et. al, 1987; VIDAL ROMANÍ et al. 1984, 1988) has showed the existence of a close relationship between the troglobiotic activity carried out by cyanobacteria, diatoms, testate amoebae, fungi, etc., and the formation of these deposits (justifying the name of biospeleothems that some authors give to them (Forti, 2001; VIDAL ROMANÍ et al., 2110 a y b)). Obviously, the greater volume of water and also its greater persistence inside a cave, when compared to what takes place outside, allow to originating the necessary conditions for the development of microorganisms (BASTIAN et al., 2009; SAIZ-JIMÉNEZ et al., 2011) transforming these caves (given their scarce light, abundance of organic matter and availability of silica) into a suitable habitat for the testate amoebae (VIDAL ROMANÍ et al., $2110 \mathrm{a}$ and b). Though a significant microbiological activity exists in the karstic environment sensu stricto (NORTHUP \& LAVOIE, 2001), the great abundance of water makes the physical processes, especially chemical, prevail with the corresponding formation of speleothems (by dissolutionprecipitation), even inhibiting the processes developed by the microorganisms that need more stable and quite environments, and essentially a slower water dynamics. Perhaps the best demonstration of what happens with the microorganisms in karstic and pseudokarstic environments is the same existence of testate amoebae, characteristic of the pseudokarst, whose tests are so small and delicate that they do not resist a short transport process and are simply destroyed by the change of the humidity conditions inside the cave, undoubtedly causing the death of the protozoan and the immediate dismemberment of its test. For the specific 
case of the pseudokarstic environments developed in massifs of igneous rocks, the organic activity influences on the formation of the biospeleothems in two phases: first, the destruction of the silicates of the rock which are dissolved in the infiltration water and second, the generation of speleothems, especially those containing amorphous opal
(VIDAL ROMANÍ et al., 2110 a y b), when Si dissolved in water precipitates due to the oversaturation by evaporation when the water contribution to the systems ends. In this work, we refer generically to all the igneous rocks grouped in 4 sets whose chemical and mineralogical compositions may vary substantially (Table 1).

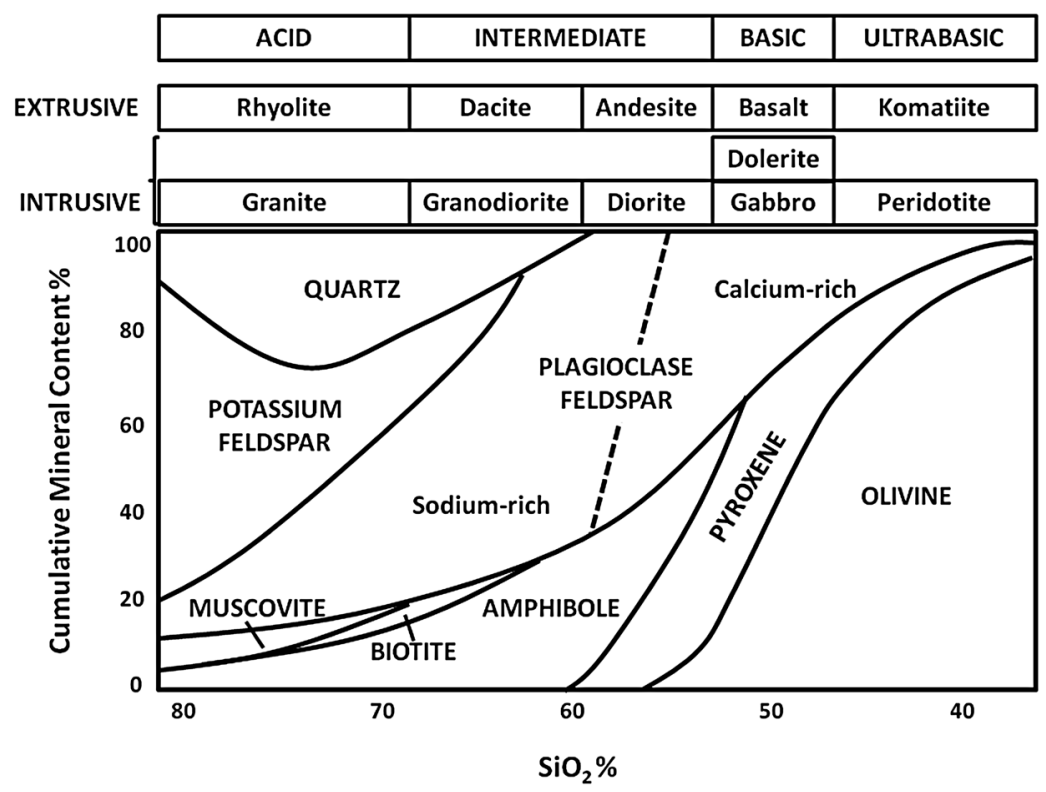

Table 1 . Types of igneous rocks (intrusive and extrusive) with their mineralogical composition and percentage of $\mathrm{SiO}_{2}$.

As it may be observed in the acid and intermediate rocks, silica is one of the most abundant chemical element (ranging between 50 and $80 \%$ ), which explains that the amorphous opal is the most frequent mineralogy of these speleothems, but not the only one, in caves of these types of rocks. On the contrary, the proportion of silica in the basic and ultrabasic igneous rocks is lower (ranging between 50 and $30 \%$ ), and in these cases it may happen that amorphous opal speleothems are scarce, do not form, or even coexist with calcium carbonate speleothems (WOO et al., 2008; BEINLICH \& AUSTRHEIM, 2012; OKLAND et al., 2012).

\section{TESTATE AMOEBAE}

Amoebae are protozoa or unicellular organisms that may live either naked or protected by a test both in subaerial or subterranean environments. The test may 
be formed by secretations of proteinaceous type, or by plates of calcite, amorphous silica (idiosomes), and in the agglutinated amoebae by mineral or organic particles like pollen grains, plates of other amoebae, or remains of other microorganisms (diatoms, collembolan, etc.) (Fig. 1) which share the subterranean environment. There is a lot of literature on amoebae species in calcareous caves (WOO et al., 2008; BEINLICH \& AUSTRHEIM, 2012; OKLAND et al., 2012) though normally referred to as naked amoebae which, together with other organisms, form part of the stygobios that lives in the water mass which circulates through the cave. This work is a study of the troglobites from caves in igneous rocks, focussed on testae amoebae that appear in the sedimentary registry (speleothems) preserved in these caves. In caves developed in igneous rocks, amoebae segregate plates of amorphous silica (idiosomes) with a specific spatial distribution pattern, size or geometry (Figs. 2 and 3). Some species develop spines on their tests perhaps to ensure their stability on the speleothem surfaces when water seeps over them (Fig. 4). Testate amoebae, also those with amorphous silica idiosomes, are not exclusive of caves in igneous rocks and are represented in subaerial environments: free continental waters (rivers, lakes, springs), soils, peat bogs or biofilms developed over tree barks (WYLEZICH et al., 2002). 

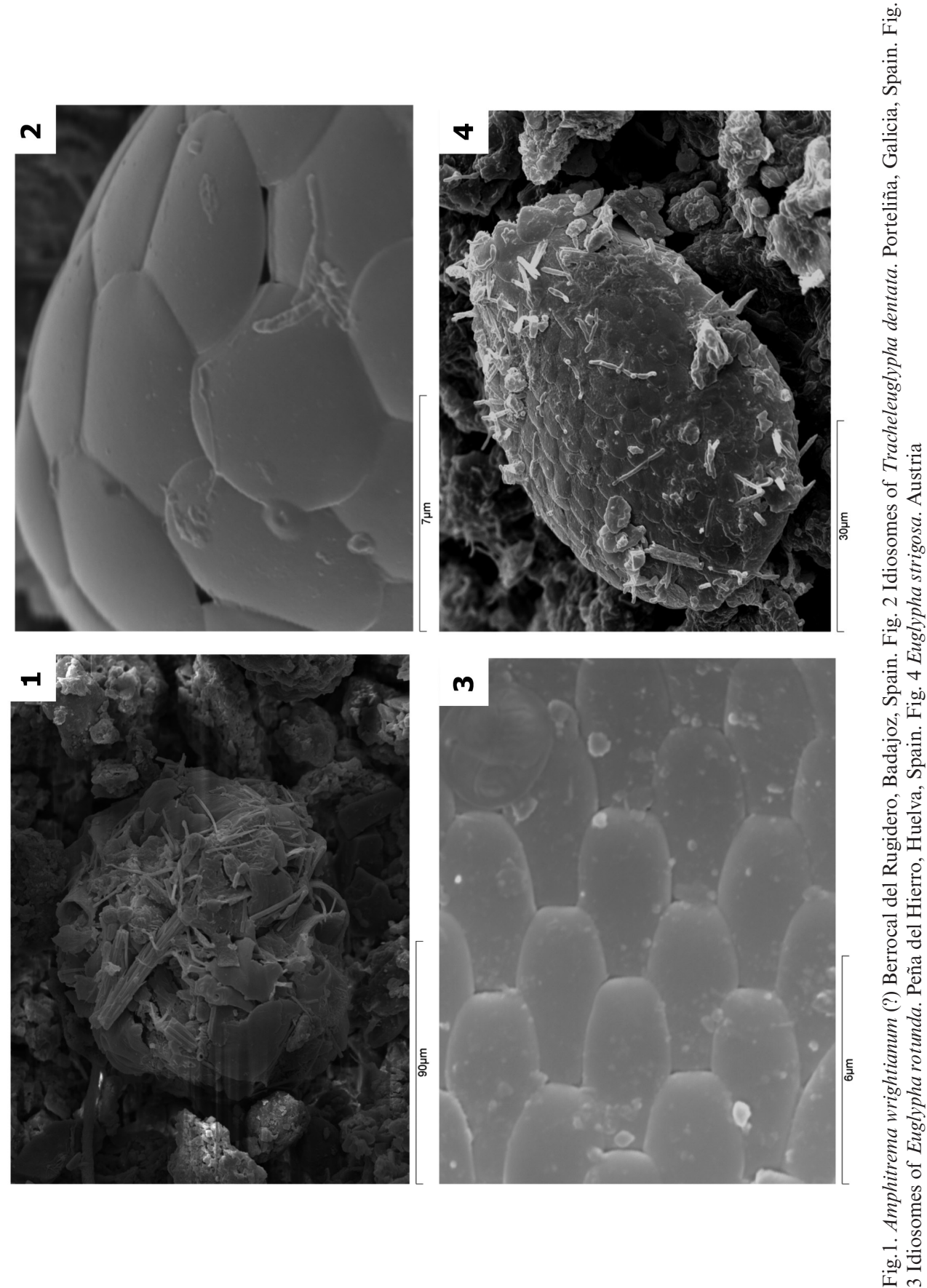

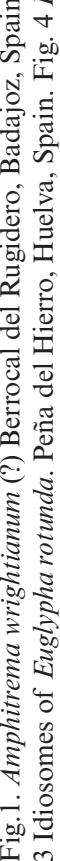




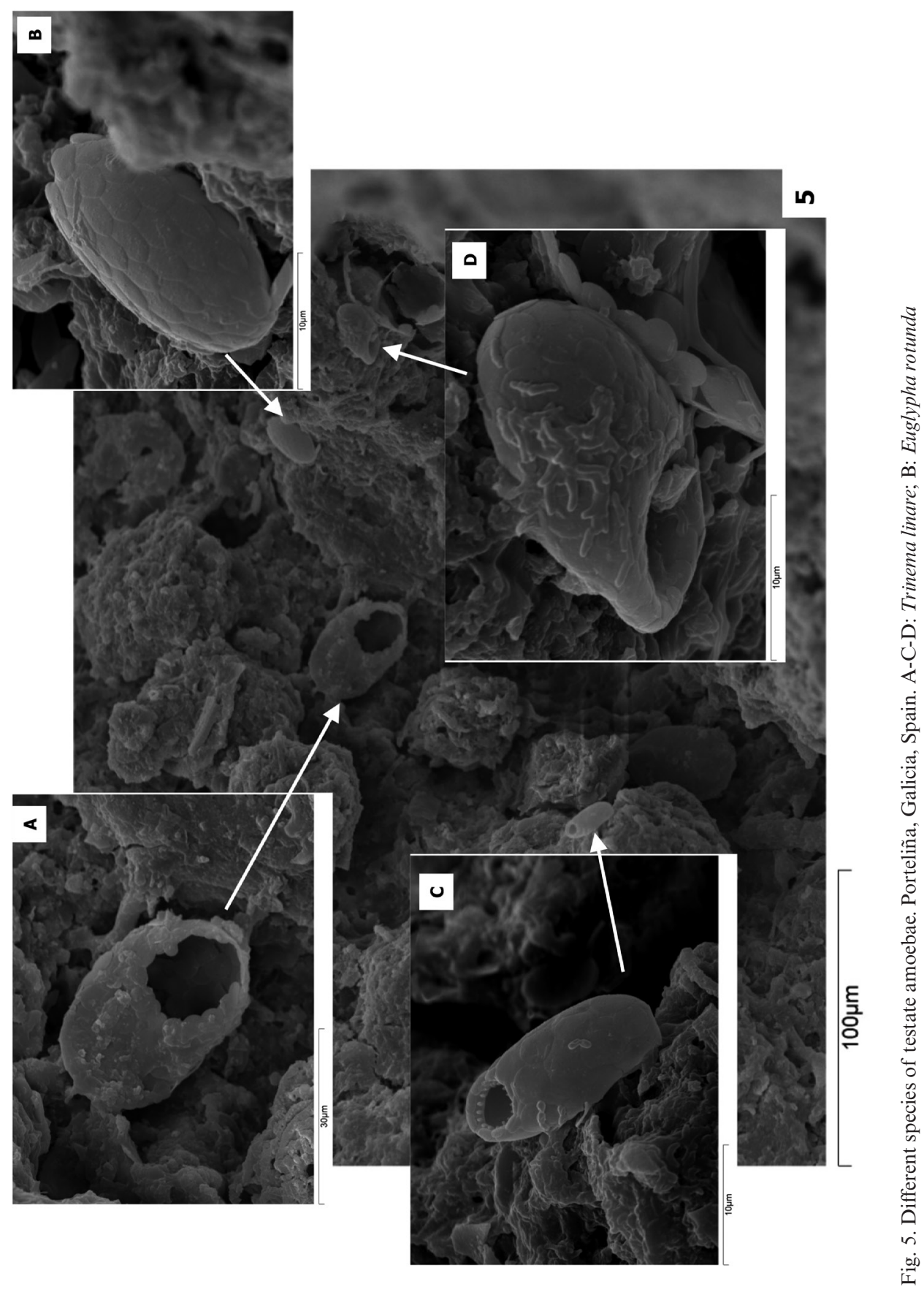


An amoeba's test has a flask-shaped form and is $100 \mu \mathrm{m}$ long and maximum $50 \mu \mathrm{m}$ width though the ones studied in our work are larger (Fig. 5). In one of the edges, there is an opening (pseudostome) frequently located on the narrowest part of the test with a border of very varied morphology (Figs. 6, 7 and 8) where there are the pseudopodia used to trap aliments and to move the protozoan. This pseudostome may be surrounded by modified plates which contain one or several teeth (Fig. 9).

Sedimentary environments with acid $\mathrm{pH}$, either caves in igneous rocks or superficial environments, are characterized by the weak drainage energy and bad water retention during the dry period, causing very quick environmental changes from wet to dry in very short time intervals. Perhaps that is why the organisms which colonize these environments, in our case the testate amoebae, develop strategies to survive draught preserving the humidity as well as to defend themselves from other predatory organisms.

\section{MATERIAL AND METHODS}

In this work, the results of the study of samples from caves in igneous rocks from different parts of the World (Spain, Portugal, Austria, Sweden, Argentina, Swaziland, Madagascar, Western and South Australia) are presented. In most of the study cases, specimens of testate amoebae associated to speleothems were identified. The samples were conveniently protected in bags or boxes depending on their fragility grade and dimensions to avoid their physical deterioration during their transportation to the laboratory. Once in the laboratory, they were examined, without previous treatment, at the stereoscopic microscope Nikon SMZ1500 and photographed with a Nikon DS.Fil in order to select the best specimens. For their observation under the SEM, they were prepared according to the standard protocol which consisted in a not very aggressive desiccation (they were stored during a week in a vacuum desiccator of silica-gel) so as to avoid the production of artifacts, essentially the polygonal cracking of the amorphous opal layers. After their desiccation, the samples were metalized by spattering with a thin gold layer of 50-100 $\AA$ with cathode pulverization equipment BAL-TEC SCD 004. The use of carbon spattering was avoided because the normal analytic determinations in this type of sample could have masked the carbon content of some of the very abundant organic remains (palynomorphs, mites, collembola, bacteria, etc.). The samples thus prepared were studied under the scanning electronic microscope JEOL JSM 6400 selecting different magnification levels to locate and identify the organic and mineral elements in each studied sample.

The sedimentary mineralogy, texture and structure of the samples were taken into consideration only as complementary information to define the dynamics and biogeochemical conditions of the environment. An inventory of the different species of amoebae identified in the speleothems is presented herein. The aspect of these protozoa is very much influenced by the time elapsed between the cave water appearance and the observation moment, obviously better preserved when the sample was taken during or immediately after the wet period of the cave.

The amoebae were located on the external surface of the speleothems protected in small depressions or in the open voids of the porous fabric of the speleothem (Figs. 10 and 11). Their preservation state depends on 

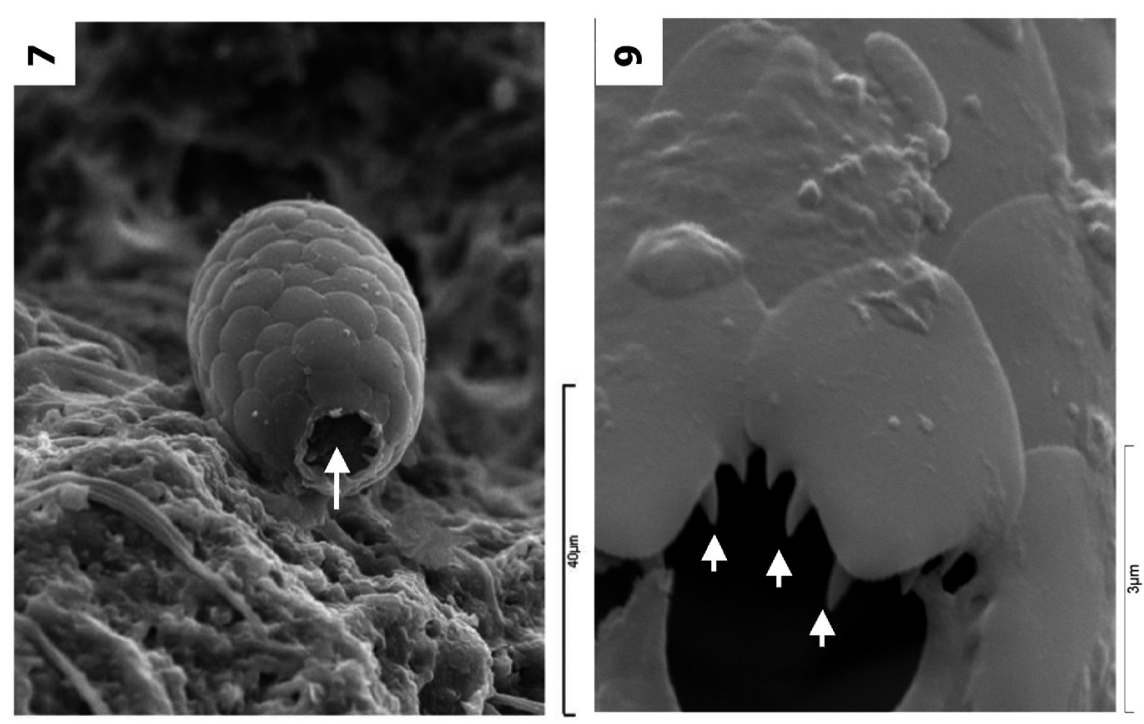

离

.00

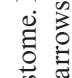

t⿱艹

导

,

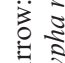

这

茫

की

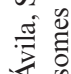

安

농

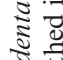

ฐ

क्ष

틍

ฐ

ㄴำ

츰
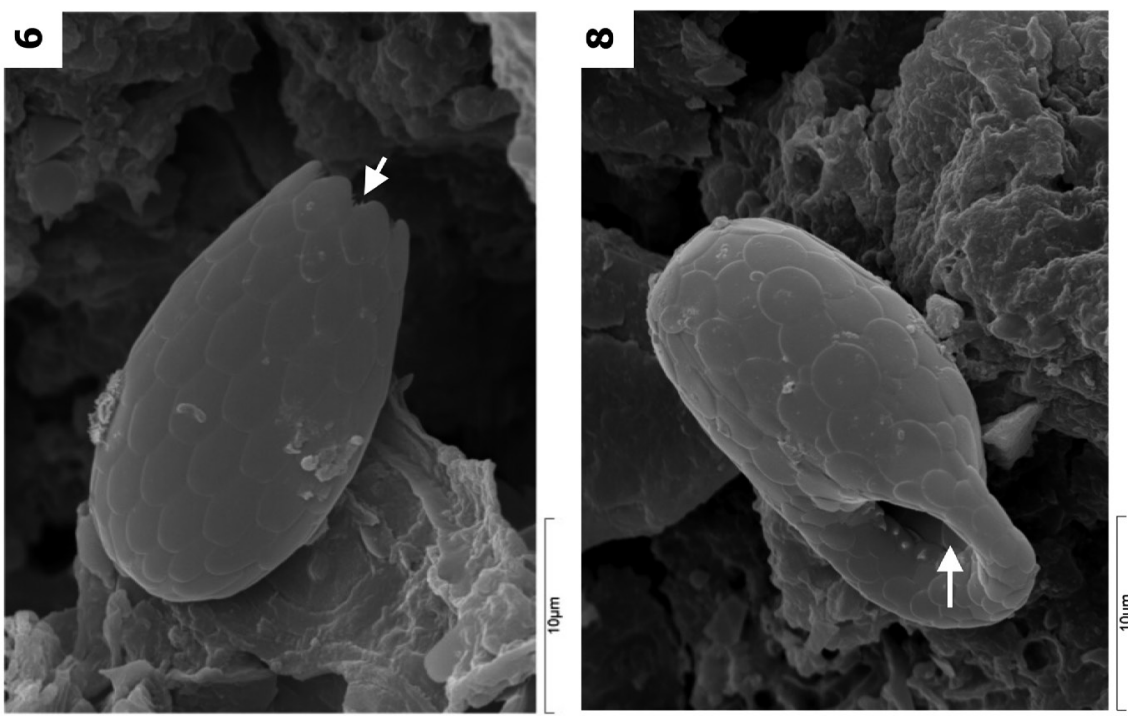

D

江

옹

谣

잉

范

产

步

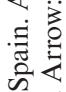

:

ن

!ี



ธี่

틀 흔

咅

ปิ

ำ

क्षे

过

का 
whether the sample was collected during the wet stage when all the amoebae were alive and the test was intact, or during the dry stage when the test could be disintegrated totally or partially. In the transition stage from dry to wet, it was observed the colonization, in different grades, of the test by cyanobacteria which could cover them completely (Figs. 12, 13 and 14). According to this interpretation, different transformation states are distinguished: intact located on the speleothem surface (Figs. 4, 6, 7 and 8 ) or in different destruction phases with the test partially collapsed by flattening (Figs. 15 and 16) or totally dismantled with release of idiosomes, which are gradually incorporated into the speleothem as elements of its sedimentary fabric (Fig 17). They may appear as isolated individuals, in sets of several specimens (not necessarily of the same specie) (Figs. 5 and 18), sometimes of different sizes (Fig. 5) and also physically associated apparently (Fig. 13 and 19). In caves developed in igneous rocks, two big types of speleothems are distinguished: flowstone (Fig. 20) and cylindrical (Figs. 21 and 22) (VIDAL ROMANÍ et al., 2010 a and b) which will deposit indistinctly on the ceiling, wall or floor of the caves. Specimens of testate amoebae were found in both types of speleothems, though in greater quantity in the cylindrical ones (Figs. 21 and 22). 

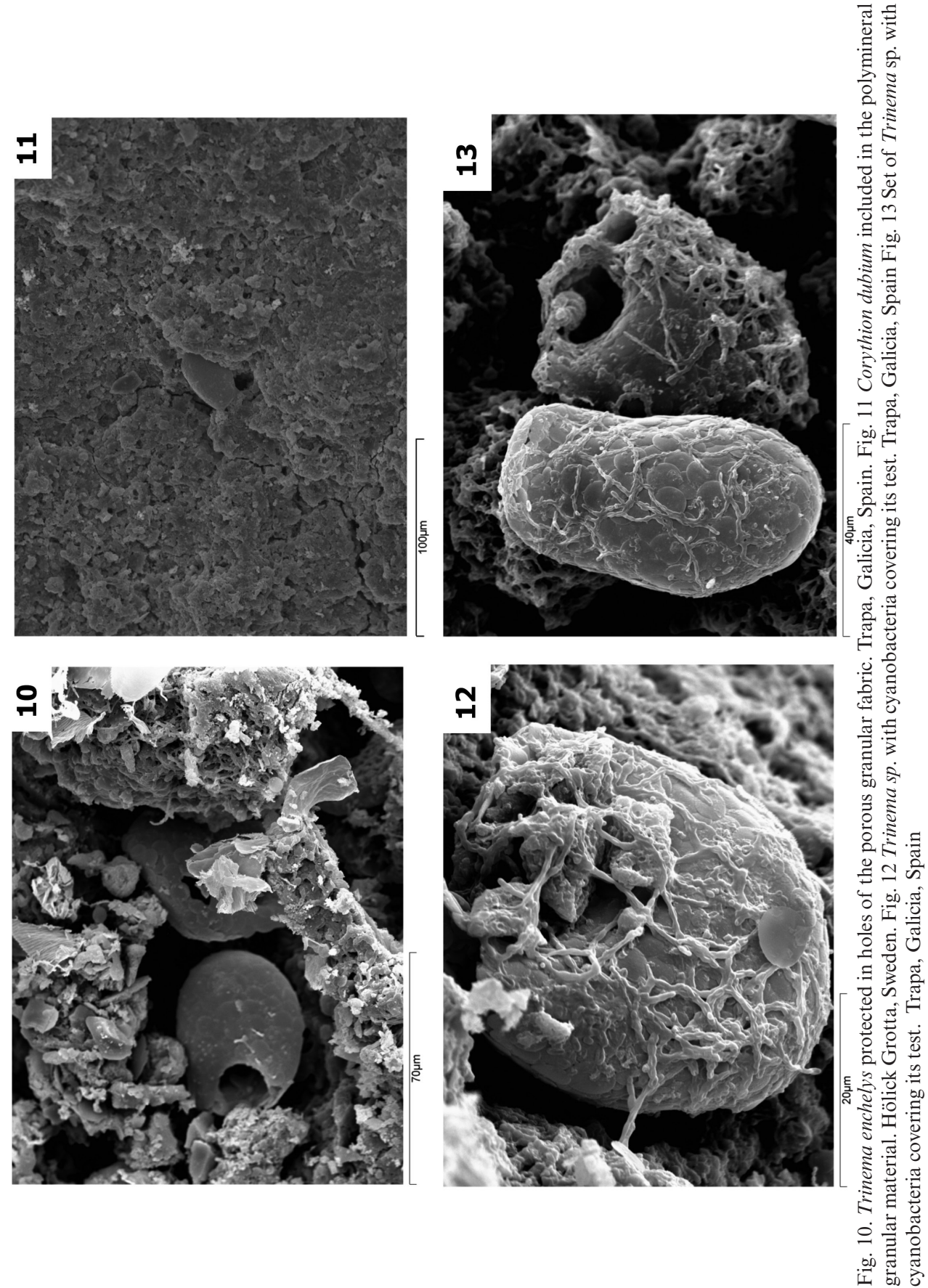

$=$,

莡

氙

कू की

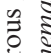

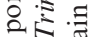

드 क

पे $\cdot \dot{0} \cdot \frac{\pi}{0}$

ข

Ð

政

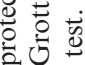

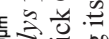

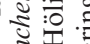

․ㅛ

洁焉

으를을

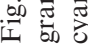



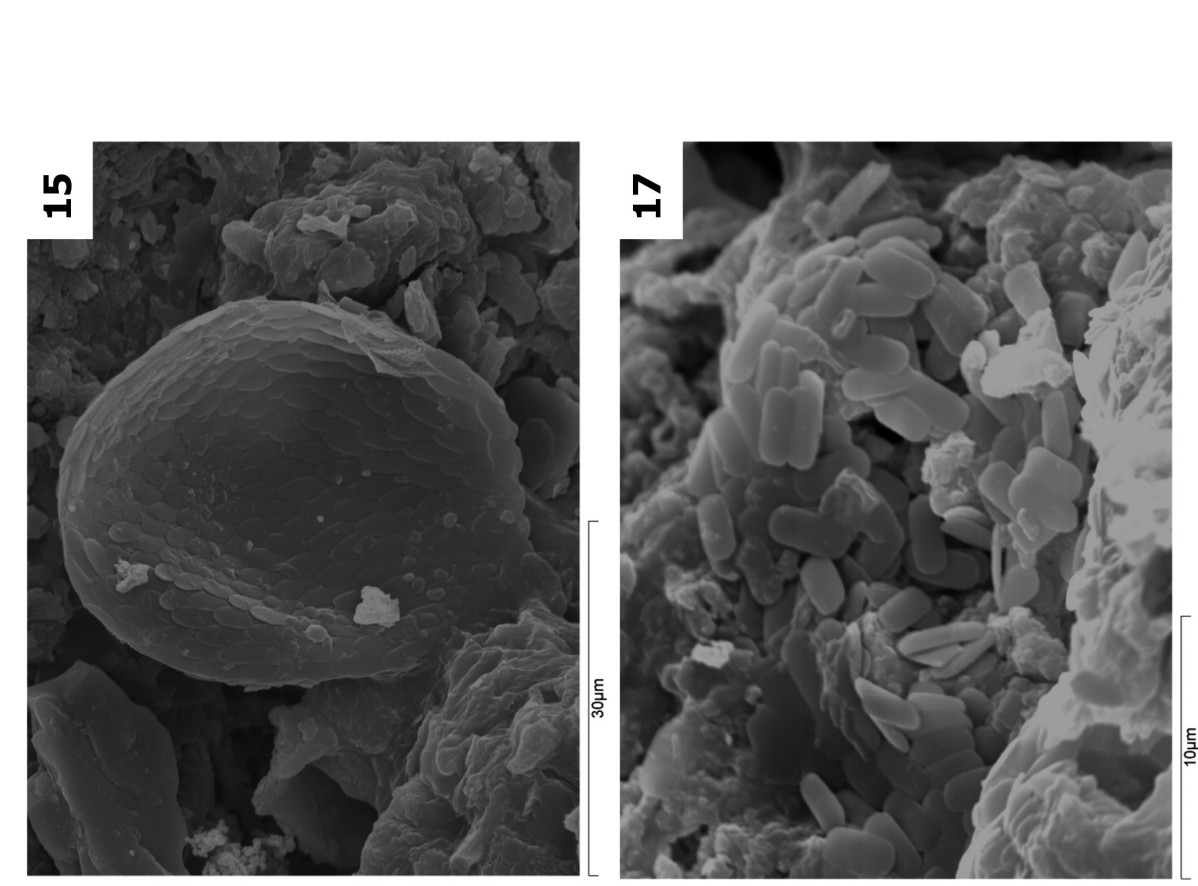

节

$\frac{2}{3}$

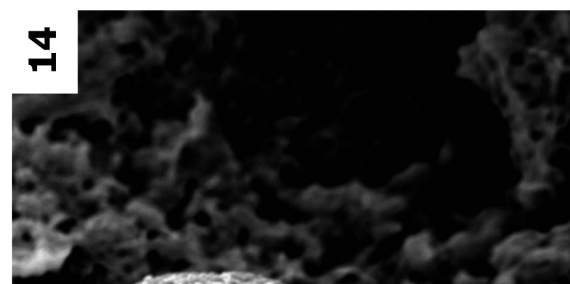

\section{o}

3,52

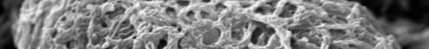

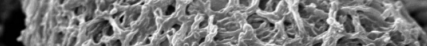

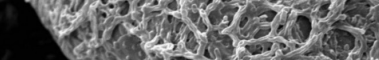
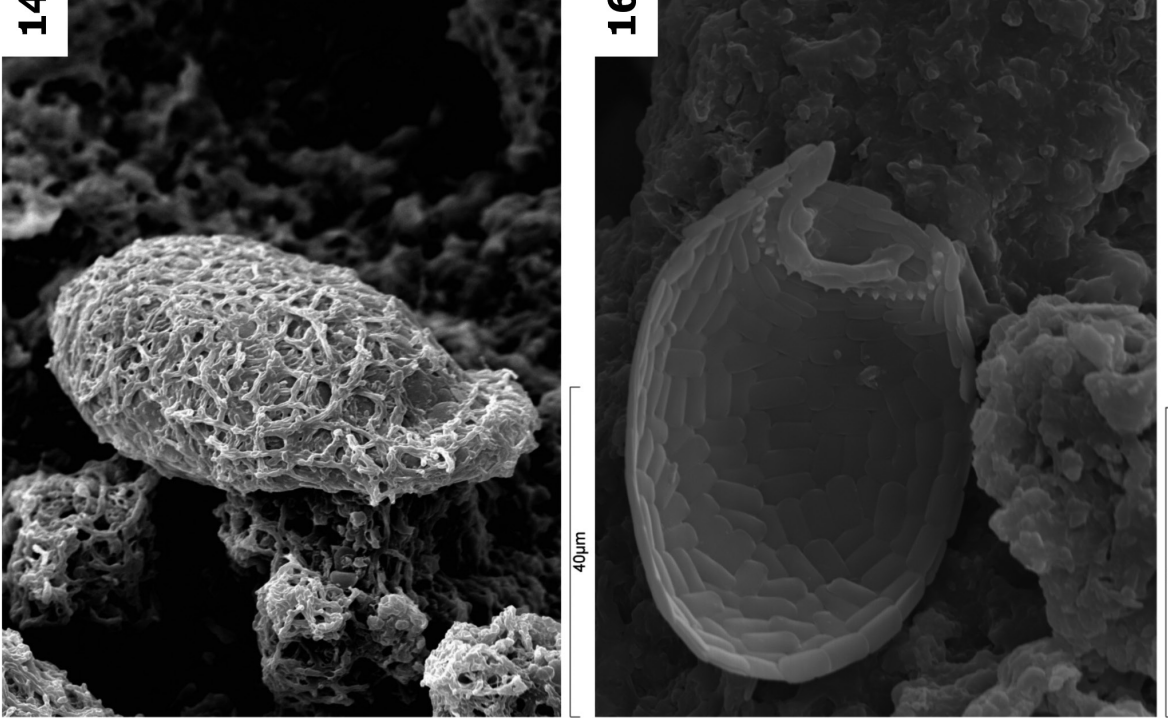

:

ฮ

造

ค. ํํㄹ

章

के

离

焉

苛这

긍

들

is

is

के

.

元

舫

苛

$\exists$

跑

$\cong$

on

寻

8

$\pi 0$

要

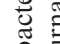

오

吾要

틀 考 웜

क्षे

8

ฐ

is

过

อิ 

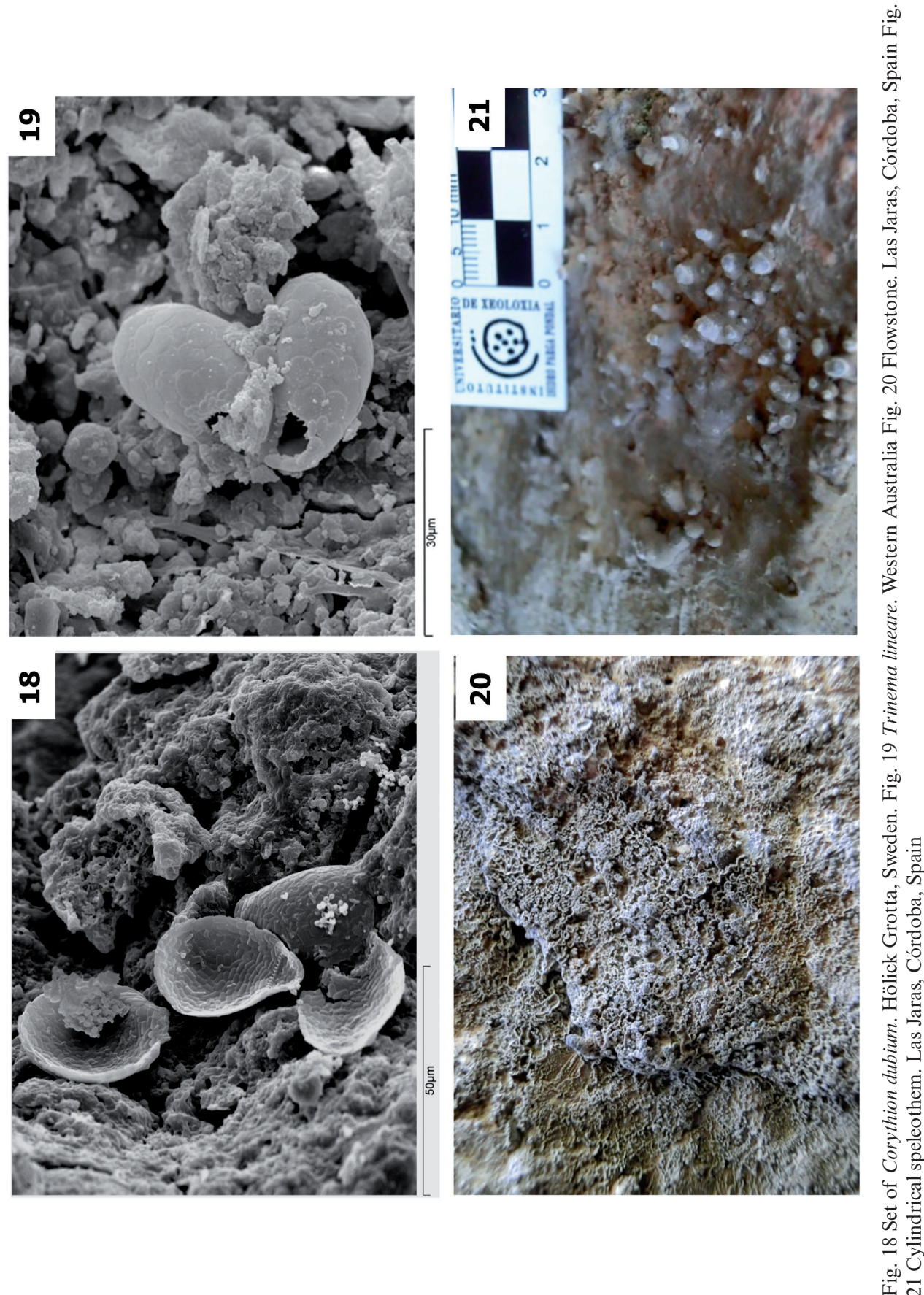

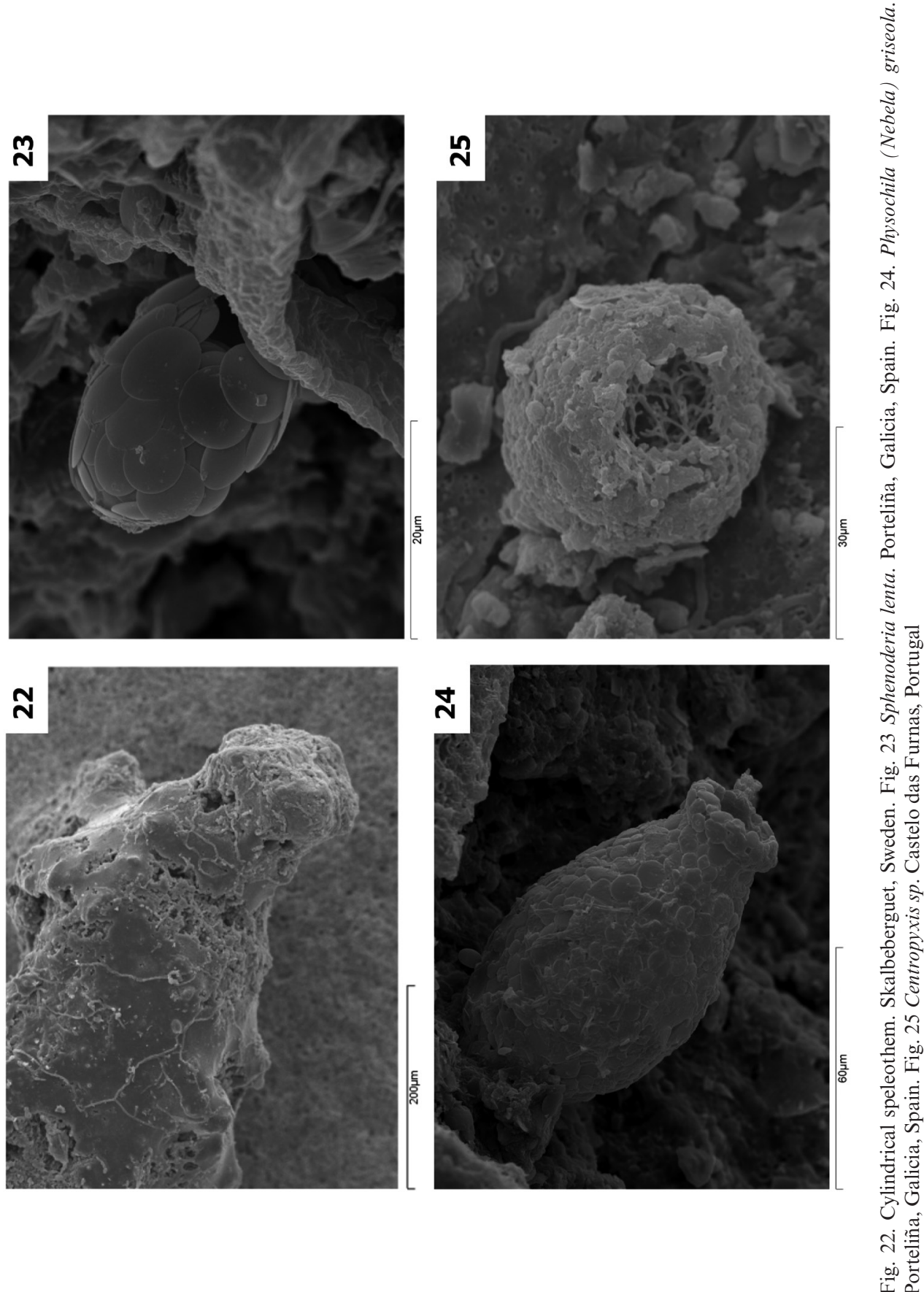


\section{RESULTS AND DISCUSSION}

The direct observations under the scanning electronic microscope and the later study of the obtained graphic documentation allowed us to identify the different species of the testate amoebae present. The habitual genera of testate amoebae from caves in igneous rocks correspond to Trinema, Euglypha, Corythion and Centropyxis with the distinct feature of having flattened morphologies and small size. Apparently, the genera inherent to edaphic environments, according to Lousier (1974, 1982), coincide with the ones found in our caves.

The following species of testate amoebae were identified:

Species from the Family Euglyphidae (Wallich, 1864): Euglypha rotunda (Wailes, 1911) (Fig. 6), Euglypha strigosa (Ehren- berg, 1872) (Fig. 4), Sphenoderia lenta (Schlumberger, 1845) (Fig. 23), Tracheleuglypha dentata (Moniez, 1888) (Fig. 7), Assulina muscorum (Greeff, 1888) (Fig. 15).

Species of the family Trinematidae (Hoogenraad \& De Groot, 1940): Trinema complanatum (Penard, 1890) (Fig. 8), Trinema enchelys (Ehrenberg, 1838) (Fig. 10), Trinema lineare (Penard, 1890) (Fig.19), Corythion dubium (Taranek, 1881) (Fig.16).

Species from the Family Nebelidae (Taranek, 1882): Physochila (Nebela) griseola (Wailes \& Penard, 1911) (Fig.24).

Some specimens provisionally assigned to the Family Centropyxidae (Jung, 1942) (Fig.25) were identified.

In the following table we can observe how the distribution of species of the analysed samples is presented:

\begin{tabular}{|c|c|c|c|c|c|c|c|c|c|c|c|c|c|c|}
\hline & $\mathbf{1}$ & 2 & 3 & 4 & 5 & 6 & 7 & 8 & 9 & 10 & 11 & 12 & 13 & 14 \\
\hline Euglypha rotunda Wailes & $x$ & & & & & & & & $x$ & $x$ & $x$ & & & \\
\hline Euglypha strigosa Ehrenberg & & $x$ & $x$ & & & & & & & & & & & \\
\hline Sphenoderia lenta Schlumberger & & & & & & & & & $x$ & & & & & \\
\hline Tracheleuglypha dentata Moniez & & & & $x$ & & & & & $\mathrm{x}$ & & & & & \\
\hline Assulina muscorum Greeff & & & & & & & $x$ & & & $x$ & & & & \\
\hline Trinema complanatum Penard & $x$ & $x$ & & & & & $x$ & & $x$ & & & & & \\
\hline Trinema enchelys Ehrenberg & & & $x$ & & & & $x$ & $x$ & & & & & & \\
\hline Trinema lineare Penard & & & $x$ & & $\mathrm{x}$ & $x$ & & & $\mathrm{x}$ & & & & & $\mathrm{x}$ \\
\hline Corythion dubium Taranek & & $\mathrm{x}$ & & & $\mathrm{x}$ & & $\mathrm{x}$ & & & $\mathrm{x}$ & $\mathrm{x}$ & $x$ & $x$ & \\
\hline Nebela griseola Penard & & & & & & & & & $x$ & & & & & \\
\hline
\end{tabular}

Table 2. Distribution of species identified in the different locations geographically marked with a number: (1) Swaziland, Gobholo; (2) Austria; (3) Western Australia and South Australia; (4) Spain, Ávila; (5) Spain, Córdoba, Las Jaras; (6) Spain, Badajoz, Berrocal del Rugidero; (7) Spain, Galicia, A Trapa; (8) Spain, Galicia, Louro; (9) Spain, Galicia, Porteliña; (10) Spain, Huelva, Peña del Hierro; (11) Portugal, Castelo da Furna; (12) Sweden, Falkberget; (13) Sweden, Hölick Grotta; (14) Sweden, Tröllhallet. 
The observations made in different caves in igneous rocks (Table 2) allowed us to elaborate a quite varied inventory of species where a few are exclusive of a location. Though the work was carried out on a geographically diverse sample (with clear prevalence of samples from Spain and Sweden) (Mapa 1), a great homogeneity in the distribution of the identified amoebae species may be observed. This indicates that, in spite of the different bioclimatic conditions of the external environment of the cave, the pseudokarstic microsystem is very similar inside; thus, in our opinion, it explains the similarity of the spectrum of the identified species. It is obvious that a greater sampling should be studied, both in the number of studied speleothems and the origin zones.

Some authors (AOKI et al. 2007) assign the testate amoebae a very important role in the silica cycle based on the fact that the high solubility of the amorphous (or biogenic) opal, main mineral of the test, provides a great mobility to the silica. However, considering the scarce volume of speleothems in caves in igneous rocks and the scarce abundance of tests that are in them, this affirmation seems to be not very plausible from the sedimentary point of view. It is convenient to take into account that most of the speleothems are formed by mineral clasts of quartz, feldspar and mica coming from the granular disaggregation of the rock due to physical weathering. The biogenic fraction (and more specifically, the amorphous opal) is reduced to a superficial film of some few micra thick that in some cases covers the whole surface of the speleothems being either cylindrical or planar, and only in cases of repeated re-dissolution gives rise to the formation of not very thick rhythmical structures. The tests will disperse over this thin film of amorphous opal (Fig. 22) but never in large concentrations of individuals. Possibly at global scale and considering the large water volumes that move in the terrestrial surface, large rates of the silica mobilization may be quantified. But at the scale of speleothems from caves in igneous rocks studied in this work, the importance of this mineral (amorphous opal) or of the silica is practically symbolic. 


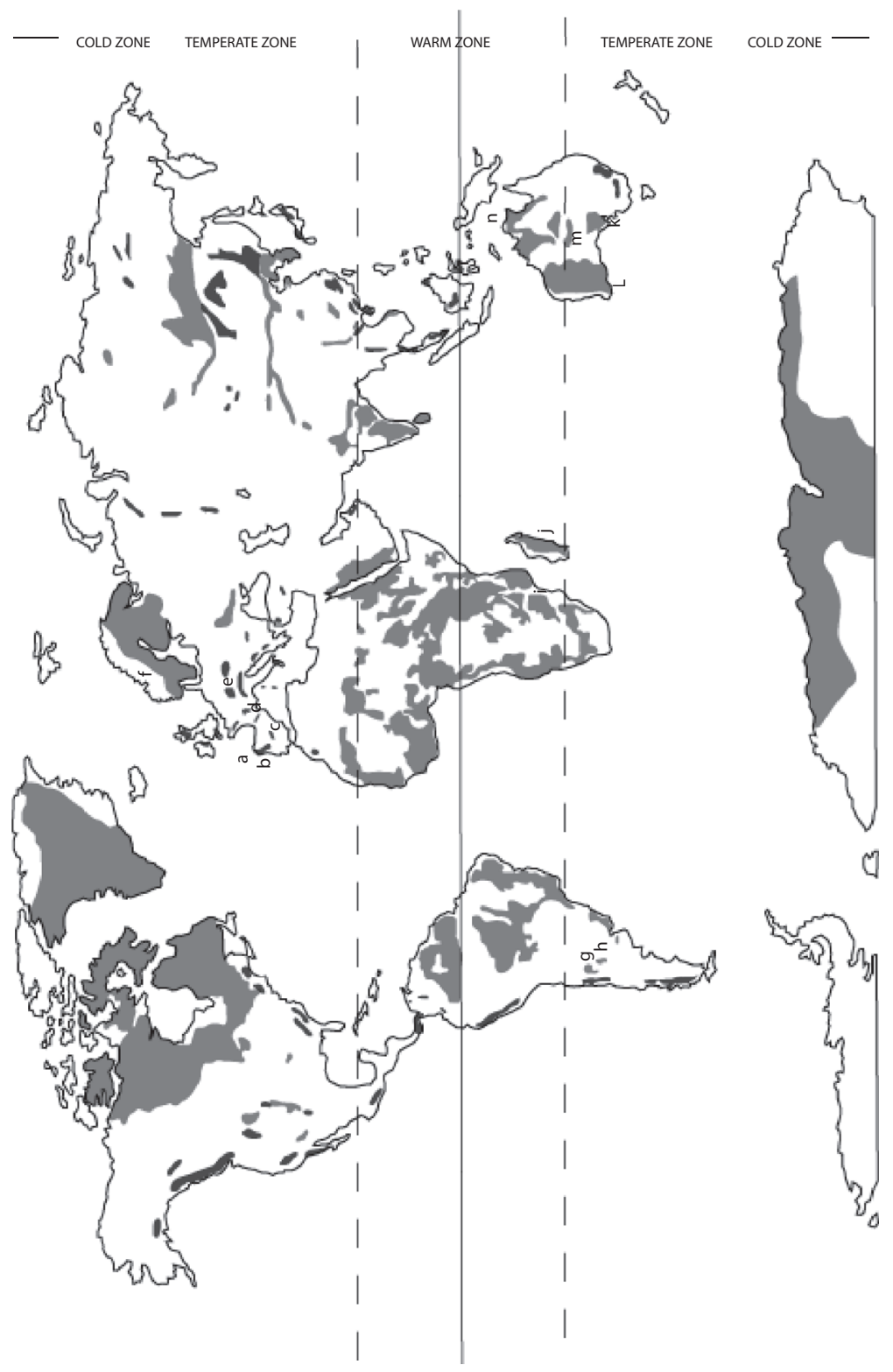

Map 1. World's climatic zones with the main granites and granitoids areas in grey. Locations from which the samples were taken: a. Galicia - Northwestern Spain; b. Minho - Northern Portugal; c. Guadarrama Sierra - Central Spain; d. Girona- Northeastern Spain; e. Austria; f. Central Sweden; g. Anillaco, La Rioja - Argentina; h. Sierra Grande de Córdoba - Argentina; i. Gobholo, Swaziland - Southeastern Africa; j. Andringrintra Massif - Madagascar; k. Eyre Peninsula - Southern Australia - Australia; 1. Hyden Rock - Western Australia - Australia; m. Devil's Marbles - Northern Territory - Australia; n. Darwin - Northern Territory - Australia 


\section{CONCLUSIONS}

Testate amoebae with amorphous opal idiosomes are common microorganisms in pseudokarstic environments developed in massifs of igneous rocks. There is a great homogeneity in the spectrum of species represented that appear to have a great independency from the weather conditions existing outside the cave and also from the type of igneous rock in which they have developed. The determinant factors seem to be the following: first, the humidity (independently from the frequency and persistence of the wet period) in the caves; second, the availability of silica in the cavity. The preservation state of the tests is a reliable microenvironmental indicator of the underground environment that allows knowing the humidity grade existing therein at the time the sample was collected: well-preserved tests in humid period, bad preserved tests in dry period, tests colonized by cyanobacteria in the reestablishment of the humidity conditions in the cave.

\section{ACKNOWLEDEMENTS}

We must thank very much Dr. Edward A. D. Mitchell, Dr. Ralf Meisterfeld and Dr. David Wilkinson who helped out with the testate amoebae identifications and specific bibliography at our beginning. We also thank Rabbe Sjöberg, Rudolf Pavuza, Rune Magnusson, Johanes Lundberg and Darron Raw for the remittance of samples of speleothems.

This work was founded with the Project PROXIES II (CGL2011-30141) of the Ministry of Economy and Competitiveness of Spain.

\section{BIBLIOGRAPHY}

AOKI, Y., HOSHINA, M. and MATSUBARA, T. (2007). Silica and testate amoebae in a soil under pineoak forest. Geoderma 142:29-35.

ARMYNOT du CHATELET, E., GUILLOT, F., RECOURT, P., VENTALON, S. and TRIBOVILLARD, N. ( 2010). Influence of sediment grain size and mineralogy on testate amoebae test construction. Comptes Rendus - Geoscience. 342(9), 710-717.

BASTIAN, F., ALABOUVETTE, C. and SAIZ-JIMENEZ, C. (2009). Bacteria and free-living amoeba in the Lascaux Cave. Res. Microbiol. 160(1), 38-40.

BEINLICH, A. and AUSTRHEIM, H. (2012). In situ sequestration of atmospheric $\mathrm{CO} 2$ at low temperature and surface cracking of serpetinized peridotite in mine shafts. Chemical Geology, 33233, 32-44.

CALDCLEUGH, A. (1829). On the geology of Rio de Janeiro. Trans. Geol.Soc. London, 2, 69-72.

COPPELLOTTI, KRUPA O. and GUIDOLIN, L. (2003). Taxonomy and ecology of ciliate fauna (Protozoa, Ciliophora) from karst caves in North-East Italy. Subterr. Biol. 1: 3-11

CLARKE, K. J. (2003). Guide to the identification of soil protozoa - testate amoebae. Soil Biodiversity Programme Research Report No. 4 ed. D. W. Sutcliffe, editor. The Ferru House, Far Sawrey, Ambleside, Cumbria: CEH-Windermere in collaboration with the Freshwater Biological Association.

FORTI, P. (2001). Biogenic speleothems: an overview. Int. J. Sepeleol., 30a(1/4), 3956. 
FORTI, P. (2005). Genetic processes of cave minerals in volcanic environments. An overview. Journal of Cave and karst studies, v.67, $\mathrm{n}^{\circ} 1,3-13$.

GARCÍA-SÁNCHEZ, A. M., ARIZA, C., UBEDA, J. M., MARTÍN-SÁNCHEZ, P. M., JURADO, V., BASTIAN, F., ALABOUVETTE, C., and SAIZJIMÉNEZ, C. (2013). Free-living amoebae in sediments from the Lascaux Cave in France. International Journal of Speleology. 42(1), 9-13.

KASHIMA, N., IRIE, T. and KINOSHITA, N. (1987). Diatom contribution of coralloid speleothems, from TogawaSsakaidani-Co Cave in Miyazaki Prefecture, Central Kyushu, Japan. International Journal of Speleology, 16, 95-1200.

LOUSIER, J. D. (1974). Effects of experimental soil moisture fluctuations on turnover rate of testate amoebae. Soil Biol Biochem. 6:19-26.

LOUSIER, J. D. (1982). Colonization of decomposing deciduous leaf litter by Testacea (Protozoa, Rhizopoda): Species succession, abundance and biomass. Oecologia 52:381-388.

MAZEI, Y., BELYAKOVA, O., TRULOVA, A., GUIDOLIN, L. and COPPELLOTTI, O. (2012). Testate amoebae communities from caves of some territories in European Russia and North-Eastern Italy. Protistology, 7: 42-50.

MITCHELL, E. A. D., CHARMAN, D. J. and WARNER, B. G. (2008). Testate amoebae analysis in ecological and paleoecological studies of wetlands: past, present and future. Biodivers. Conserv. 17(9), 2115-2137.

NORTHUP, D. E. and LAVOIE, K. H. (2001). Geomicrobiology of caves: a review. Geomorcrobiology Journal, 18, 199-222.
OGDEN, C. G. and HEDLEY, R. H. (1980). An Atlas of Freshwater Testate Amoebae. Oxford: Oxford University Press.

OKLAND, I., HUANG, S., DAHLE, H., THORSETH, I. H. and PEDERSEN, R. B. (2012). Chemical Geology, 318319- 75-87.

RAVEN, J. A. and GIORDANO, M. (2009). Biomineralization by photosynthetic organisms: Evidence of coevolution of the organisms and their environment? Geobiology 7:140-154.

SMITH, H. G., BOBROV, A. and LARA, E. (2008). Diversity and biogeography of testate amoebae. Biodivers. Conserv. 17(2), 329-343.

VIDAL ROMANÍ, J. R., GRAJAL, M., VILAPLANA, J. M., RODRÍGUEZ, R., MACIAS, F., FERNÁNDEZ, S. and HERNÁNDEZ PACHECO, E. (1979). Procesos actuales: micromodelado en el granito de Monte Louro, Galicia España (Proyecto Louro). Actas IV Reunión G. E. T. C., Banyoles (España), 246-266.

VIDAL ROMANÍ, J. R. (1983). El Cuaternario de la provincia de A Coruña. Geomorfología granítica. Modelos elásticos de formación de cavidades. Tesis Doctoral. Servicio de Publicaciones. Universidad Complutense, Madrid.

VIDAL ROMANÍ, J. R. and VILAPLANA, J. M. (1984). Datos preliminares para el estudio de espeleotemas en cavidades graníticas. Cadernos do Laboratorio Xeolóxico de Laxe, 7: 305-324.

VIDAL ROMANÍ, J. R., TWIDALE, C. R., BOURNE J. and CAMPBELL, E. M. (1998). Espeleotemas y formas constructivas en granitoides. In: Investigaciones recientes en la Geomorfología española. (Ortiz, A. G. \& Franch, F. S., Eds.) $1^{\text {a }}$ edición. Barcelona: Actas Reunión de 
Geomorfología (Granada). 777-782.

VIDAL ROMANÍ, J. R., BOURNE, J. A., TWIDALE, C. R. and CAMPBELL, E. M. (2003). Siliceous cylindrical speleothems in granitoids in warm semiarid and humid climates. Zeitschrift für Geomorphologie, 47(4): 417-437.

VIDAL ROMANÍ, J. R. and VAQUEIRO, M. (2007). Types of granite cavities and associated speleothems: genesis and evolution. Nature Conservation 63, 41-46.

VIDAL ROMANÍ, J. R., SANJURJO SÁNCHEZ, J., VAQUEIRO RODRÍGUEZ, M. and FERNÁNDEZ MOSQUERA, D. (2010 a). Speleothem development and biological activity in granite cavities. Geomorphologie. Relief, processus, environment, (4), 337- 346.

VIDAL ROMANÍ, J. R., SANJURJO SÁNCHEZ, J., VAQUEIRO, M. and FERNÁNDEZ MOSQUERA, D. (2010 b). Speleothems of Granite Caves. Comunicações Geológicas, 97: 71-80.

WALOCHNIK, J. and MULEC, J. (2009). Free-living amoebae in carbonate precipitating microhabitats of karst caves and a new vahlkampfiid amoeba, Allovahlkampfia spelaea gen. nov., sp. nov.
Acta Protozool. 48(1), 25-33.

WEBB, J. A. and FINLAYSON, B. L. (1984). Allophane and opal speleothems from granite caves in south-east Queensland. Australian Journal of Earth Sciences , 31, 341-349.

WILKINSON, D. M. and MITCHELL, E. A. D. (2010). Testate amoebae and nutrient cycling with particular reference to soils. Geomicrobiol.J. 27(6-7), 520-533.

WILKINSON, D. M. (2008). Testate amoebae and nutrient cycling: peering into the black box of soil ecology. Trends in Ecology and Evolution. 23(11), 596-599.

WOO, K. S., CHOI, D.W. and LEE, K. C. (2008). Silicification of cave corals from some lava tube caves in the Jeju Island, Korea: Implications for speleogenesis and a proxy for paleoenvironmental change during the Late Quaternary. Quaternary International, 176-177, 82-95.

WYLEZICH， C., MEISTERFELD, R., MEISTERFELD, S. and SCHLEGEL, M. (2002). Phylogenetic analyses of small subunit ribosomal RNA coding regions reveal a monophyletic lineage of euglyphid tesytate amoebae (order Euglyphyda). J. Eukaryot. Microbiol., 49(2), 108-118. 